\title{
Management, Survival Strategies, and Host Range of Colletotrichum acutatum on Strawberry
}

\author{
Stanley Freeman ${ }^{1}$ \\ Department of Plant Pathology, ARO, The Volcani Center, Bet Dagan 50250, Israel
}

Additional index words. anthracnose, Colletotrichum gloeosporioides, control, Fragaria $\times$ ananassa, fungal pathogens, plasticulture

\begin{abstract}
Colletotrichum spp. are broad-range pathogens, meaning that many species can infect a single host and a single species can infect diverse hosts. For example, Colletotrichum acutatum J.H. Simmonds affects a wide range of crops, causing disease symptoms on apple, almond, anemone, citrus, lupin, peach, pecan, strawberry, and others, whereas Colletotrichum gloeosporioides Penz. (Penz. \& Sacc.) can affect many of the previous hosts as well. Anthracnose is one of the major fungal diseases of strawberry occurring worldwide. In Israel, the disease is caused primarily by the species $C$. acutatum. The pathogen causes irregular leaf spot, bud rot, petiole and stolon necrosis, and black spot on fruit. The pathogen is most destructive when it causes root necrosis and crown rot, which usually kill the plants in nurseries and transplants in the field. To maintain a disease-free crop, nuclear and foundation stock material, as well as field nurseries, must be routinely monitored and tested for presence of the pathogen. Strawberry cultivation using plasticulture as an overhead cover of the crop can significantly control anthracnose disease incidence by reducing inoculum spread and infection, both in nurseries and in production fields. $C$. acutatum from strawberry can survive on several cultivated plant species, such as pepper, eggplant, tomato, bean, and weed species, without causing disease symptoms. This indicated that they may serve as a potential inoculum reservoir for strawberry infection between seasons. Although . acutatum survives in soil under certain conditions, no specific resting structures have been observed indicating that the pathogen does not behave as a typical soilborne fungus.
\end{abstract}

\section{ANTHRACNOSE DISEASE}

Anthracnose, incited by the species Colletotrichum acutatum, is one of the major fungal diseases of strawberry affecting all parts of the plant during nursery and production stages (Maas, 1998). Additional species of Colletotrichum-C. gloeosporioides and C. fragariae Brooks - also cause similar symptoms of disease in this crop. In the nursery, lesions are formed on stolons that eventually girdle the runners, and unrooted daughter plantlets, distal to the lesions, wilt and die. Most plant organs are extremely susceptible to disease. Infected leaves (leaf spot; irregular leaf spot), buds (rot), flowers (blight), and green and ripe fruit (black spot) can all be infected, and this can lead to total yield loss (Howard et al., 1992). Mother plants affected by anthracnose may collapse entirely due to crown rot. Root necrosis incited by $C$. acutatum may also stunt plants (Freeman and Katan, 1997). Infected transplants can spread the disease from the nursery to the field. Splash dispersal of conidia is the primary means of dissemination of inoculum (Madden et al., 1992), with optimum conducive temperatures ranging from 15 to $30{ }^{\circ} \mathrm{C}$.

\section{MANAGEMENT OF ANTHRACNOSE}

Nuclear and foundation stock material, as well as field nurseries, must be routinely monitored and tested for presence of anthracnose to maintain a disease-free strawberry crop. The Colletotrichum species must be identified accurately, as C. acutatum is tolerant to various fungicides such as benomyl, whereas C. gloeosporioides is not (Freeman

${ }^{1}$ To whom correspondence should be addressed; e-mail freeman@volcani.agri.gov.il et al., 1998). This can be done effectively with molecular biology techniques, such as arbitrarily primed polymerase chain reaction (PCR), species-specific PCR, and internal transcribed spacer (ITS) sequencing of the ribosomal DNA (Denoyes-Rothan et al., 2003; Freeman et al., 2001b). Healthy propagation material is a prerequisite for disease control. In Israel, certified disease-free strawberry propagation material is tested by law twice a year for the major fungal pathogens including Colletotrichum, nematodes, and viruses, to guarantee the supply of clean material to farmers.

Plastics are used widely for plant protection during cultivation of strawberry (Freeman and Gnayem, 2004). Plastic mulches spread on the soil surface are used to reduce many diseases in several ways; soil solarization, fumigation, and as a physical barrier between soil and fruit. Different types of plastics are also used for overhead covering and protection. Strawberry fruiting fields may be grown under low tunnels (cloches) or walk-in greenhouses to reduce splash dispersal. The ability to aerate under plasticulture also alleviates moisture accumulation and so reduces inoculum levels.

Much work has been done on splash dispersal of the pathogen by overhead irrigation and rains (Madden et al., 1992; Yang et al., 1992). The spread of C. acutatum on fruit in Israel has been minimized by growing the crop under cloches or walk-in greenhouses. Plants situated along the edges of plastic cloches and tunnels are exposed to rainfall and may become infected with anthracnose. These plants should be removed if they are exposed to continuous water splash to avoid serving as a possible source of inoculum. Strawberry cultivation in Florida, Mississippi, and Louisiana is not protected by plastic covering, thus a substantial amount of the crop may be lost because the pathogen is dispersed by rainfall (Howard et al., 1992). Other physical and environmental factors may serve to spread anthracnose disease, therefore, a polyethylene tarp on the soil surface can provide a physical barrier to prevent the spread of propagules on windborne sand particles and prevent insects and other means, such as agricultural equipment and workers' shoes, from distributing the pathogen (Howard et al., 1992).

Drip irrigation in strawberry cultivation, at both the nursery and field-production stages, will benefit any integrated pest management (IPM) program (Durner et al., 2002). Subsurface irrigation can also be used to reduce free moisture and has been implemented recently in certain field nurseries in Israel. Likewise, in fruiting fields, overhead irrigation used to establish transplants should be ended as soon as possible in favor of drip irrigation to prevent dispersal of the inoculum.

Soil disinfestation (solarization, fumigants, and steaming) will aid in the management of anthracnose as this pathogen is known to survive in the soil (Eastburn and Gubler, 1990; Freeman et al., 2002). The fumigant methyl bromide effectively controls a wide spectrum of microorganisms pests and weeds. Methyl bromide treatment completely controlled anthracnose when infested mummified fruits were buried at depths of 10 and $20 \mathrm{~cm}$ in the field (Freeman et al., 2002). However, with the eventual phase-out of this fumigant, anthracnose and other soilborne pathogens may increase in the future. Soil solarization, which captures solar energy in the form of heat under sheets of clear, transparent polyethylene, is able to reduce fungal inocula and other soilborne pests (Katan, 1981). Solarization effectively controlled $C$. acutatum buried at two depths in soil under field conditions in Israel (Freeman et al., 2002) and other fungal pathogens, e.g., Verticillium microsclerotia and Phytophthora cactorum inoculum, in soil in 
California (Hartz et al., 1993; Himelrick et al., 1995).

Strawberry nurseries are usually established in disinfested soils, therefore it is important for plant material to be diseasefree because any pathogen accompanying the propagation material can readily become established and spread in this new environment due to the creation of a "biological vacuum" and lack of antagonistic microflora in the fumigated soil. It has been reported that bare transplants heated at $49{ }^{\circ} \mathrm{C}$ for $5 \mathrm{~min}$ were essentially free of anthracnose, and this provided a nonchemical treatment to ensure healthy plant stock (Freeman et al., 1997; Strand, 1994). Although heat treatments may be a welcome alternative to chemical fungicides to protect and cure strawberry anthracnose, their long-term effect on plant development and yield needs to be addressed. Moreover, all infected material (runners, whole plants, and fruits) should be removed from the cultivation area and not left in rows because it serves as an additional inoculum source.

The establishment of transplants in the field is one of the most critical stages for field production. Plants that are killed by strawberry anthracnose during the first month after planting are routinely replaced by new transplants, which delays fruit production and thus substantially reduces revenue. Various fungicides were assessed for their ability to control strawberry anthracnose incited by the fungus C. acutatum under laboratory, greenhouse, and field conditions. For example, the effective dose causing 50\% inhibition of mycelial growth $\left(\mathrm{ED}_{50}\right)$ was $0.05 \mu \mathrm{g} \cdot \mathrm{mL}$ for prochloraz-Mn (Freeman et al., 1997). As a result, single-dip prochloraz treatments both at the nursery establishment and at the transplant stages have become routine practice for all farmers in Israel, regardless of whether plants have visible anthracnose symptoms. Single-dip treatments have minimal impact on the environment, as entire fields are not sprayed after planting. Although mild prochloraz phytotoxicity was observed, crop yield does not appear to be affected and fungicide-tolerant or resistant strains of $C$. acutatum have not yet been reported (Freeman et al., 1997).

\section{HOST SPECIFICITY}

Colletotrichum spp. are broad-range pathogens; many species can infect a single host, and single species can infect diverse hosts (Freeman et al., 1998). Examples of single hosts affected by numerous Colletotrichum species include strawberry infected by three Colletotrichum species, namely C. acutatum, C. fragariae, and C. gloeosporioides; avocado and mango infected by both C. acutatum and C. gloeosporioides; almond and other deciduous fruits infected by C. acutatum or C. gloeosporioides; citrus is affected by four different Colletotrichum diseases, namely, postbloom fruit drop and key lime anthracnose incited by $C$. acutatum and shoot dieback and leafspot incited by
C. gloeosporioides (Freeman et al., 1998). Additional hosts affected by multiple Colletotrichum species include coffee, cucurbits, pepper, tomato, and others (Bailey and Jeger, 1992).

In contrast, single species of Colletotrichum commonly infect multiple hosts. Examples include $C$. acutatum, which infects many fruit and ornamental crops including apple, avocado, almond, anemone, blueberry, citrus, grape, lupin, peach, strawberry, and tamarillo; and C. gloeosporioides, which is found on a wide range of fruit crops including almond, avocado, apple, and strawberry (Afanador-Kafuri et al., 2003; Freeman et al., 1998). Examples of other species with multiple host ranges include Colletotrichum coccodes, Colletotrichum capsici, and Colletotrichum dematium (Bailey and Jeger, 1992).

\section{CROSS-INFECTION POTENTIAL}

Cross-infection potential has been reported among different species of Colletotrichum on a variety of tropical, subtropical, and temperate fruits (Alahakoon et al., 1994; Bernstein et al., 1995). Although artificial inoculation will not usually assess host specificity reliably, it indicates the potential for infection (Freeman et al., 1998). In studies conducted in Israel, it was shown that $C$. gloeosporioides isolates from almond, apple, avocado, and mango, as well as $C$. acutatum isolates from anemone, apple, peach, and strawberry, infected detached fruits from the different hosts (Freeman and Shabi, 1996; Freeman et al., 2001a). These results demonstrated cross-infection potential between two species representing distinct subpopulations. Likewise, in Israel, certain C. acutatum anemone and strawberry populations causing anthracnose were genotypically identical and indistinguishable when compared by arbitrarily primed PCR and ITS sequence of genomic DNA (Freeman et al., 2000, 2001b). Furthermore, isolates from anemone and strawberry caused disease on both plant species in artificial inoculations. This demonstrated the cross-infection potential because in some areas where infection occurred both crops are cultivated in close proximity (Freeman et al., 2000).

\section{HOST RANGE AND ASYMPTOMATIC STRATEGIES OF SURVIVAL OF C. ACUTATUM}

The host range and specificity of C. acutatum obtained from strawberry plants has been examined on pepper, eggplant, tomato, bean, and strawberry under greenhouse conditions. The fungus was recovered from all plant species periodically over a 3-month period but caused disease symptoms only on strawberry (Freeman et al., 2001a). The authenticity of the isolates as C. acutatum was validated by PCR-specific primers, and the pathogen was detected in inoculated tissues epiphytically and endophytically (up to 12 weeks). Leandro et al. (2001) reported that secondary conidia are formed on straw- berry leaves without infection or host penetration, and this may be one mechanism that enables the pathogen to survive and proliferate on different host and nonhost leaf surfaces. On strawberry, germinating conidia formed branched, thick, coiled hyphae including large numbers of appressoria that are essential for plant penetration; thereafter, the fungus developed rapidly, filling the mesophyll with dense mycelium that invaded the cells and caused necrosis of the tissue (Horowitz et al., 2002). In nonpathogenic interactions on pepper, eggplant, and tomato, the pathogen grew epiphytically and did not invade the plant. The conidia germinated, producing thin, straight germ tubes, and the appressoria that were produced generally failed to germinate and penetrate leaf tissues. Where the appressoria did manage to penetrate the leaf tissue, penetration occurred only several days after inoculation and was restricted to the intercellular spaces of the first cell layers of infected tissue without causing any visible damage (Horowitz et al., 2002). Much of the new fungal biomass continued to develop on the surface of inoculated organs in the nonpathogenic interactions. Colletotrichum acutatum has also been isolated from healthy-looking, asymptomatic plants of the weed species, Vicia and Conyza, growing in infected strawberry nurseries (Freeman et al., 2001a).

The habitation of many plant species including weeds by $C$. acutatum suggests that plants that are not considered hosts of C. acutatum may serve as a potential inoculum source for strawberry infection and may permit the pathogen to survive between seasons. This is in accordance with the detection of $C$. fragariae on the weeds Stellaria, Sesbania, Senna, Amsinckia, and Vicia species growing in containers and in and around nurseries in Florida (Brooks, 1931; Howard and Albregts, 1973; Howard et al., 1992), and of C. gloeosporioides from strawberry on noncultivated hosts in the same areas (Xiao et al., 2004).

Although C. acutatum has been shown to survive in the soil, on plant debris, and in fumigated field soil, the main source of inoculum is assumed to originate on infected strawberry plant material from the nursery (Eastburn and Gubler, 1990). However, the pathogen may be introduced in contaminated soil, on field equipment, or may be splashdispersed or blown in from surrounding vegetation that may carry the fungus without visible symptoms (Strand, 1994).

Colletotrichum acutatum, which infects many crops including strawberry, has the potential to affect other plant species and survive asymptomatically on alternative hosts. To maintain an anthracnose-free environment, periodic checks must be conducted to determine that propagation material is disease-free. Certain agrotechnical procedures that reduce free moisture, such as drip and subsurface irrigation, will restrict the spread of pathogen propagules. Various plasticulture technologies, such as high tunnels and cloches, will reduce and protect from water-splash-dispersed inoculum. 


\section{Literature Cited}

Afanador-Kafuri, L., D. Minz, M. Maymon, and S. Freeman. 2003. Characterization of Colletotrichum isolates from tamarillo, passiflora and mango in Colombia and identification of a unique species from the genus. Phytopathology 93:579-587.

Alahakoon, P.W., A.E. Brown, and S. Sreenivasaprasad. 1994. Cross-infection potential of genetic groups of Colletotrichum gloeosporioides on tropical fruits. Physiol. Mol. Plant Pathol. 44:93-103.

Bailey, J.A. and M.J. Jeger. 1992. Colletotrichum: biology, pathology and control. $\mathrm{CAB}$ Int., Wallingford, U.K

Bernstein, B., E.I. Zehr, R.A. Dean, and E. Shabi. 1995. Characteristics of Colletotrichum from peach, apple, pecan, and other hosts. Plant Dis. 79:478-482.

Brooks, A.N. 1931. Anthracnose of strawberry caused by Colletotrichum fragariae, $\mathrm{n}$. $\mathrm{sp}$. Phytopathology 21:739-744.

Denoyes-Rothan, B., G. Guérin, C. Délye, B. Smith, D. Minz, M. Maymon, and S. Freeman. 2003. Genetic diversity and pathogenic variability among isolates of Colletotrichum from strawberry. Phytopathology 93:219-228.

Durner, E.F., E.B. Poling, and J.L. Maas. 2002 Recent advances in strawberry plug transplant technology. HortTechnology 12:545-550.

Eastburn, D.M. and W.D. Gubler. 1990. Strawberry anthracnose: detection and survival of Colletotrichum acutatum in soil. Plant Dis. 74: 161-163.

Freeman, S. and N. Gnayem. 2004. Effect of plasticulture on strawberry plant production. Small Fruits Res. 4:21-32.

Freeman, S., S. Horowitz, and A. Sharon. 2001a. Pathogenic and non-pathogenic lifestyles in Colletotrichum acutatum from strawberry and other plants. Phytopathology 91:986-992.
Freeman, S. and T. Katan. 1997. Identification of Colletotrichum species responsible for anthracnose and root necrosis of strawberry in Israel. Phytopathology 87:516-521.

Freeman, S., T. Katan, and E. Shabi. 1998. Characterization of Colletotrichum species responsible for anthracnose diseases of various fruits. Plant Dis. 82:596-605.

Freeman, S., D. Minz, M. Maymon, and A. Zveibil. 2001b. Genetic diversity within Colletotrichum acutatum sensu Simmonds. Phytopathology 91:586-592.

Freeman, S., Y. Nizani, S. Dotan, S. Even, and T. Sando. 1997. Control of Colletotrichum acutatum in strawberry under laboratory, greenhouse and field conditions. Plant Dis. 81:749-752.

Freeman, S. and E. Shabi. 1996. Cross-infection of subtropical and temperate fruits by Colletotrichum species from various hosts. Physiol. Mol. Plant Pathol. 49:395-404.

Freeman, S., E. Shabi, and T. Katan. 2000. Characterization of Colletotrichum acutatum causing anthracnose disease of anemone (Anemone coronaria L.). Appl. Environ. Microbiol. 66: $5267-5272$.

Freeman, S., Z. Shalev, and J. Katan. 2002 Survival in soil of Colletotrichum acutatum and C. gloeosporioides pathogenic on strawberry. Plant Dis. 86:965-970.

Hartz, T.K., J.E. De Vay, and C.L. Elmore. 1993. Solarization is an effective soil disinfestations technique for strawberry production. HortScience 28:104-106.

Himelrick, D.G., F.M. Woods, W.A. Dozier, Jr., and J.D. Williams. 1995. Soil fumigation and soil solarization in the annual-hill strawberry plasticulture system. Adv. Strawberry Res. 14: 69-72.

Horowitz, S., S. Freeman, and A. Sharon. 2002. Use of GFP-transgenic strains to study patho- genic and non-pathogenic lifestyles in Colletotrichum acutatum. Phytopathology 92:743749.

Howard, C.M. and E.E. Albregts. 1973. Cassia obtusifolia, a possible reservoir for inoculum of Colletotrichum fragariae. Phytopathology 63:533-534.

Howard, C.M., J.L. Maas, C.K. Chandler, and E.E. Albregts. 1992. Anthracnose of strawberry caused by the Colletotrichum complex in Florida. Plant Dis. 76:976-981.

Katan, J. 1981. Solar heating (solarization) of soil for control of soilborne pests. Ann. Rev. Phytopathol. 19:211-236.

Leandro, L.F.S., M.L. Gleason, and F.W. Nutter, Jr. 2001. Germination and sporulation of Colletotrichum acutatum on symptomless strawberry leaves. Phytopathology 91:659-664.

Maas, J.L. 1998. Compendium of strawberry diseases. APS Press, St. Paul, MN.

Madden, L.V., L.L. Wilson, X. Yang, and M.A. Ellis. 1992. Splash dispersal of Colletotrichum acutatum and Phytophthora cactorum by short-duration simulated rains. Plant Pathol. 41:427-436.

Strand, L.L. 1994. Integrated pest management for strawberries, p. 142. Publication 3351. Regents of the University of California, Division of Agriculture and Natural Resources, Oakland, CA.

Xiao, C.L., S.J. MacKenzie, and D.E. Legard. 2004. Genetic and pathogenic analyses of Colletotrichum gloeosporioides isolates from strawberry and noncultivated hosts. Phytopathology 94:446-453.

Yang, X., L.V. Madden, D.L. Reichard, L.L. Wilson, and M.A. Ellis. 1992. Splash dispersal of Colletotrichum acutatum and Phytophthora cactorum from strawberry fruit by single drop impactions. Phytopathology 82 : 332-340. 